\title{
Book Review: Biologic Psychiatry for the Biologist
}

John P. Seibyl, M.D.

Thomas Jefferson University, Philadelphia, Pennsylvania

Follow this and additional works at: https://jdc.jefferson.edu/jeffjpsychiatry

Part of the Psychiatry Commons

Let us know how access to this document benefits you

\section{Recommended Citation}

Seibyl, M.D., John P. (1990) "Book Review: Biologic Psychiatry for the Biologist," Jefferson Journal of Psychiatry. Vol. 8 : Iss. 1 , Article 16.

DOI: https://doi.org/10.29046/JJP.008.1.013

Available at: https://jdc.jefferson.edu/jeffjpsychiatry/vol8/iss1/16

This Article is brought to you for free and open access by the Jefferson Digital Commons. The Jefferson Digital Commons is a service of Thomas Jefferson University's Center for Teaching and Learning (CTL). The Commons is a showcase for Jefferson books and journals, peer-reviewed scholarly publications, unique historical collections from the University archives, and teaching tools. The Jefferson Digital Commons allows researchers and interested readers anywhere in the world to learn about and keep up to date with Jefferson scholarship. This article has been accepted for inclusion in Jefferson Journal of Psychiatry by an authorized administrator of the Jefferson Digital Commons. For more information, please contact: JeffersonDigitalCommons@jefferson.edu. 


\title{
Biologic Psychiatry for the Biologist
}

\author{
PSYCHOPHARMACOLOGY: THE THIRD GENERATION OF PROGRESS \\ Edited by Herbert Y. Meltzer, M.D. \\ New York, Raven Press, 1987 \\ 1824 pages, $\$ 160.00$
}

\section{John P. Seibyl, M.D.}

As psychiatry moves into the next decade, the need to keep pace with the explosion of information in the neurosciences becomes increasingly important to clinical care, and also increasingly difficult. As a new psychiatric resident, I was intimidated by the confusing and sometimes fragmented sources available for providing background to understanding the complex biological treatments of my patients. Psychopharmacology: The Third Generation of Progress, published under the aegis of the American College of Neuropsychopharmacology, the prestigious American biological psychiatry organization, is a single, comprehensive text that addresses the needs of biologically-oriented clinicians.

This volume is an extensive survey of basic and clinical neuroscience by over 300 authors containing 184 chapters and over 1800 pages. This book is not a how-to manual of dosing, side effects, and treatment indications. Rather, Psychopharmacology: The Third Generation of Progress offers an in-depth general survey of basic and clinical neuroscience that is the foundation of rational pharmacotherapy.

While the advantages of a single volume are evident, the sheer size of this text may be a source of discouragement in approaching a relevant topic. Nonetheless, the book is reasonably well-organized and material generally accessible. The volume is divided into three main sections: basic neurobiology, biological psychiatry, and clinical psychopharmacology. This organization attempts to separate preclinical and clinical material, although for many topics there is overlap and one finds material of preclinical interest buried in a clinical review, as well as some redundancy between chapters. Nonetheless, it was useful to find similar material highlighted in different ways. For example, the seven chapters devoted to the biology and treatment of anxiety disorders present support for noradrenergic dysregulation in a number of different contexts including animal models, human pharmacologic challenge paradigms, and treatment studies. The spectrum of topics is comprehensive, including all major psychiatric disorders, anatomy and physiology of brain monoamine systems, ethical issues in drug trials, basic pharmacokinetics, substance abuse, research designs, and strategies for future biological research. Overall, figures and 
illustrations are well-placed and serve to facilitate the quick acquisition of points in the chapters, although a number of chapters would do well with further graphic illumination of the complex material packed into dense text.

There are several notable omissions in this reference, including the absence of chapters on the neurobiology of sleep and biological theories of personality disorders. Also, like many texts written by multiple authors, the quality of chapters is uneven and the prose stylistically variable. The exponential growth of information in the neurosciences has already made some sections dated; this is, unfortunately, an inescapable problem with a reference of this sort. I suspect many readers will use this volume as the first step in a literature review of a selected topic. It would have been helpful to include the complete reference including titles to articles cited in the text, even at the expense of publishing two volumes. Nonetheless, I would consider making an investment in a textbook whose scope and depth make it an important resource for the training psychiatrist or neurologist, or failing this, insuring that your department library has this volume available. Psychopharmacology: The Third Generation of Progress fills an important need for an accessible summary of the neurosciences for both the clinical psychiatrist and basic scientist and is a valuable contribution to the field. 